\title{
The buccal mucosa in protein-calorie deficiency in the pig
}

\author{
BY BERNARD T. SQUIRES \\ Human Nutrition Research Unit, Nutrition Building, National Institute for Medical \\ Research, Mill Hill, London, N.W. 7 \\ (Received 24 October 1962-Revised 25 April 1963)
}

The buccal mucosa, chiefly human, in malnutrition, has been studied in recent years, but very little has been published on the microscopic appearances of the superficial epithelial cells in protein-calorie deficiency. It has been shown (Squires, 1958,1961 ) that degenerative changes occur in the superficial mucosal cells of human patients suffering from apparent general malnutrition and that, if appropriate treatment is instituted, such changes are reversible.

To summarize the findings briefly, if a scraping is taken from the healthy mucosa, the superficial cells, $20-80 \mu \mathrm{m}$ in diameter with a conspicuous central oval nucleus $5^{-20} \mu \mathrm{m}$ across, tend to desquamate in clumps or plaques; they are plump with welldefined edges, and stain well. The cells are comparatively resistant to mechanical injury, the proportion of broken or mutilated cells in the smear being $5-10 \%$. Besides epithelial cells, in any one field several leucocytes are usually to be seen.

In primary or secondary malnutrition, characteristic changes occur. The cells no longer tend to cling together, but are mainly separate, many lose their sharpness of outline and appear 'moth-eaten' and shrunken, the proportion of broken and mutilated cells is greatly increased, up to $70 \%$ of the number examined, the staining is poor, and there is a great increase in the number of leucocytes, both granular and non-granular. These appearances are so typical and easily observed that they have been employed with some success as a rough and cheap screening method for the mass detection of malnutrition amongst Bechuana schoolchildren (Squires, 1958, 196I) and also as evidence of recovery, but owing to the primitive conditions and lack of personnel no regular quantitative records taken over long periods could be obtained, nor could the question as to the nature of the nutrient deficiency responsible for the appearances be easily answered. It is the object of this paper to provide evidence that protein-calorie deficiency causes the changes in the superficial mucosal cells. (The question of increase in leucocytes is not examined here.)

It has now been possible to examine buccal smears from piglets maintained under controlled conditions and fed at varying protein levels with and without added carbohydrate, as detailed by Friend, Heard, Platt, Stewart \& Turner (I96I). The effects upon the buccal mucosa of diets that would produce conditions resembling marasmus and, with the addition of carbohydrate, kwashiorkor in human infants could be studied quantitatively. 


\section{EXPERIMENTAL}

Animals. Material was provided from nine piglets, litter-mates aged about 3 weeks at the beginning of the experiment, which lasted I33 days.

Diet. All animals received a basal low-protein (LP) diet, containing about $6 \%$ protein and similar to that of NDPCal $=3.5 \%$ used previously at this Unit (Friend et al. 1961), with the exception of a slight modification in the salt content. As the number of pigs was limited and other examinations were to be made on the group, the following procedure was adopted. Pigs I and 2, controls, received the LP diet in which $20 \%$ casein replaced an equal amount of $\operatorname{starch}(20 \mathrm{CLP}$; NDpCal $=8.3 \%$ ). Pigs $3^{-6}$ received the LP diet only. Pigs 7-9 received the LP diet together with a supplement of carbohydrate, $100 \mathrm{~g}$ daily until the $14^{\text {th }}$ day and thereafter $200 \mathrm{~g}$ $(\mathrm{LP}+\mathrm{CH})$, providing NDPCal $=2 \cdot 6-2 \cdot 8 \%$, according to the amount of carbohydrate given (see below).

Pigs $2,3,4,7$ and 8 were killed for other purposes at various times up to the 78 th day. On the 91st day, the diet of pig 6 (LP) was changed to $20 \mathrm{CLP}$, on which the pig was maintained for the rest of the experiment. On the $65^{\text {th }}$ day, the carbohydrate supplement was omitted from the diets of pigs 7-9. Pig 9 was maintained thereafter on LP diet for 3 weeks, after which 20 CLP diet was substituted as for pig 6 .

All pigs received from the Ist day until the $\mathrm{I}_{4}$ th day $300 \mathrm{~g}$ diet daily, excluding the carbohydrate supplement, from the ${ }_{15}$ th to the 3 ist day $400 \mathrm{~g}$ daily, after which the amount was reduced to $300 \mathrm{~g}$ daily. The reduction was made because the pigs on LP and $\mathrm{LP}+\mathrm{CH}$ diets began to refuse their food when fed at the $400 \mathrm{~g}$ level.

Examination of mucosa. Smears were obtained by gentle but firm scraping of the buccal mucosa opposite to or a little higher than the line of closure of the teeth (if taken lower, food debris tends to form a large proportion of the scraping) with any suitably sized and shaped blunt instrument, e.g. a nickel spatula. The material was then transferred to a drop of water or saline on an ordinary 3 in. $\times I$ in. slide, and a smear made as if for a blood film. The smear was then immersed in Papanicolaou's fixative (50\% diethyl ether, $50 \%$ rectified spirit) before it had time to dry, and left for $\mathrm{I}-2 \mathrm{~h}$, after which it could be transported if required. For staining, haematoxylin and eosin, Ernst-Gram, Papanicolaou's and Shorr's stains have all been employed with success. Indeed, it is possible to dispense with staining by use of the doubleillumination method devised by MacConaill (1955).

An attempt was made with human subjects to standardize as far as possible the conditions for obtaining a smear by the use of a simple mechanical aid, with an action similar to that of a biopsy tube with a sliding knife to remove the superficial layers of epithelium, but it proved to have no advantage over the simpler methods of scraping as described above, nor could it be used for pigs.

Recording methods. The characteristics of $(a)$ decrease in staining intensity and (b) damage to the cells were examined with a view to obtaining quantitative records.

(a) The possibility of using results from photo-electric estimation of staining density of affected cells with a photo-electric cell or a photo-amplifier was exhaustively investigated, but both methods were found to be impracticable, not because of 
any fault in the apparatus, but because of the lack of a homogeneous layer of cells sufficient to fill the field, even with the use of an eye-piece mask and at a high magnification, owing to the separation and fragmentation of the cells.

(b) The estimation of the proportion of damaged and broken cells was therefore adopted. As many cells as possible were counted in each smear, usually not less than 500 ; several smears were made on each occasion, as in a poor smear there may be less than 500 cells, for many may be piled up in such a way as to make counting with any

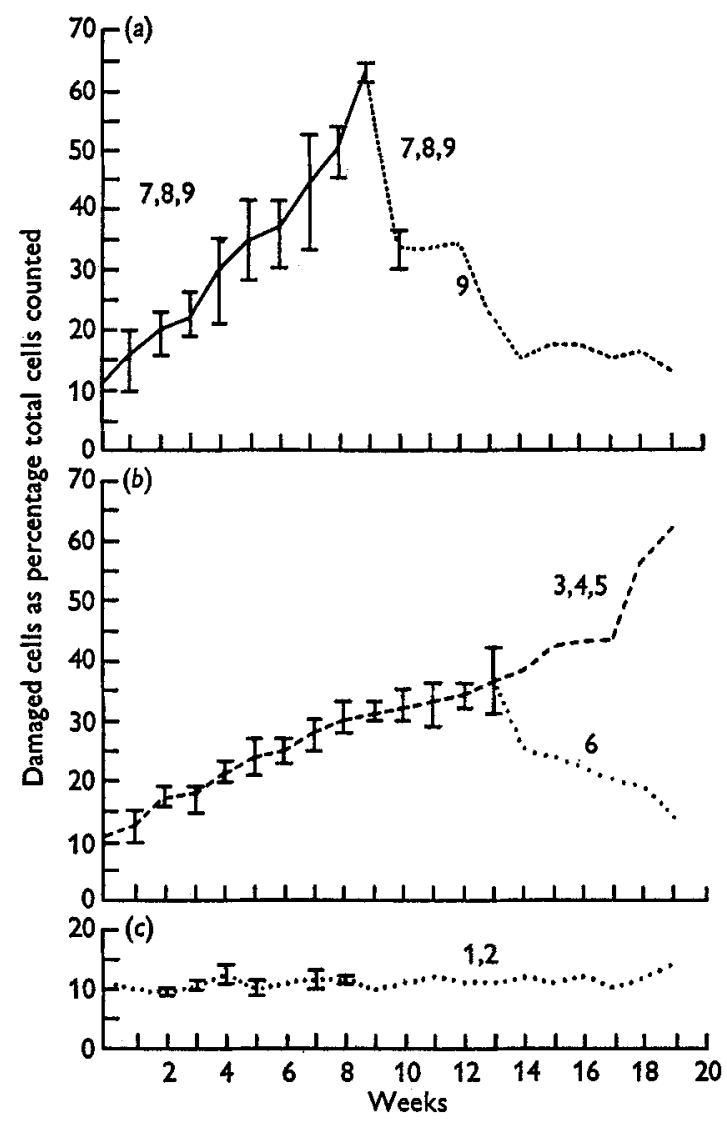

Fig. I. Mean weekly percentage of damaged cells in buccal mucosa of pigs according to diet, with ranges where appropriate. The numbers denote the pigs.,$- \mathrm{LP}+\mathrm{CH}$ diet of NDpCal $=2.6-2.8 \% ;---$, LP diet of NDpCal $=3.5 \% ; \ldots, 20$ CLP diet of NDpCal $=8.3 \%$.

pretence to accuracy impossible. For the same reason no clumps of cells containing more than five were counted. The counting was performed with a $\frac{2}{3}$ in. or $\frac{1}{6}$ in. objective, with occasional use of higher powers when required. All fragments of broken cells containing the nucleus were counted, but fragments consisting of cytoplasm only were not included. (The majority of dead or dying superficial cells in pigs show nuclei, albeit faintly, since in these animals, as in man, the buccal mucosal cells do not generally proceed to complete keratinization, as in rodents.) Mutilated, but 
not folded, cells were also included. Counts were made in triplicate from each smear. Smears, besides being obtained repeatedly from each animal before the beginning of the experiment, were taken twice weekly during it.

\section{RESULTS}

The findings are given in Fig. I, and are reasonably clear cut. In pigs I and 2, the controls on 20 CLP diet (Fig. I $c$ ), the proportion of abnormal cells varied over the range $7-14 \%$ with a mean of $10.9 \%$ during the entire experimental period, similar to the range $(5-10 \%)$ in healthy human subjects.

Pigs 3-5 on diet LP showed a more or less steady rise in the proportion of broken and mutilated cells throughout; pig 6 on the same diet gave a very similar rise until the 9Ist day, after which the diet was changed to 20 CLP. Within a week of this change the proportion of broken and mutilated cells fell from 42 to $25 \%$, and subsequently over the next 5 weeks to the control range (Fig. $\mathrm{r} b$ ).

Pigs 7-9, on $\mathrm{LP}+\mathrm{CH}$ diet, exhibited a more rapid and greater increase in the proportion of broken and mutilated cells until the 63rd day, after which the carbohydrate supplement was omitted, with the result that all these counts fell to the LP range within I week, at which stage pigs 7 and 8 were killed for other purposes. Pig 9 was kept on the LP diet until the 86th day, after which the 20 CLP diet was substituted for LP. Within the next 7 weeks, the count of broken and mutilated cells fell to the 20 CLP range also.

The exaggerated response obtained on $\mathrm{LP}+\mathrm{CH}$ diet, compared with that observed in pigs on LP diet only, emerges clearly, and the reversibility of the changes in the buccal mucosa subsequent to the raising of the $\mathrm{NDpCal}$ percentage is well marked (Fig. I $a$ ).

The gross skin changes noted by Godwin (1960) in pigs on similar diets were present in these animals, to the greatest extent in those on $\mathrm{LP}+\mathrm{CH}$ diet, and to a lesser degree in those on LP diet only. Rapid improvement occurred after alteration in diets.

\section{DISCUSSION}

Within the limits of this experiment, increase in the proportion of broken and mutilated cells, due probably to an increase in cell fragility and lowered resistance to trauma involved in scraping, was clearly associated with deficiency in protein intake. The increased responses of the pigs on $\mathrm{LP}+\mathrm{CH}$ diet were in keeping with a variety of other exaggerated responses, physiological, histological, and biochemical, detailed by Heard, Platt \& Stewart (1958) for pigs on similar diets.

Results similar to those obtained for the buccal mucosa of pigs have been obtained for dogs on a low-protein diet (Squires, unpublished). It is suggested therefore that the findings with human subjects are also due to protein deficiency, and that the uses of the method now discussed may be advantageous where facilities for other methods of examination are lacking. 
SUMMARY

1. The effect of protein-deficient diets has been observed on young pigs fed at varying protein levels, and investigated by microscopic examination of scrapings from the buccal mucosa, wherein the proportion of broken and mutilated cells was ascertained by serial counts.

2. Nine pigs in three groups were maintained on diets providing $(a) \mathrm{NDpCal}=$ $8.3 \%,(b)$ NDpCal $=3.5 \%$ and $(c)$ NDpCal $=2.6-2.8 \%$.

3. The group on NDpCal $=8.3 \%$ showed a range of $7-14 \%$ of broken and mutilated cells throughout the experiment. The other groups on diets of $\mathrm{NDpCal}=3.5 \%$ and NDpCal $=2 \cdot 6-2 \cdot 8 \%$ showed the same range initially, but the proportion of broken and mutilated cells increased slowly in the first group, and more rapidly and extensively in the second.

4. Increase in the protein content of the diet for these latter groups to the level of the first group resulted in a prompt reduction in the proportion of broken and mutilated cells to that shown by the first group on diet of $\mathrm{NDpCal}=8 \cdot 3 \%$.

5. These findings are similar to those in African children suffering from marasmus and kwashiorkor.

I am indebted to the Medical Research Council for a grant, and to Professor B. S. Platt for laboratory facilities.

\section{REFERENCES}

Friend, C. J., Heard, C. R. C., Platt, B. S., Stewart, R. J. C. \& Turner, M. R. (196r). Brit. F. Nutr. I5, 23 r.

Godwin, K. O. (1960), Proc. Nutr. Soc. 19, xxxviii.

Heard, C. R. C., Platt, B. S. \& Stewart, R. J. C. (1958). Proc, Nutr. Soc, 17, xli.

MacConaill, M. A. (1955). Irish F. med. Sci. 6th Ser. 358, 459.

Squires, B. T. (1958). Cent. Afr. F. Med. 4, no. 3, p. I04.

Squires, B. T. (1961). Proc, Nutr. Soc. 20, xix. 